\title{
Synthesis of Highly Active Pt-Pd-Cu/C Catalysts for Formic Acid Oxidation
}

\author{
Yange Suo ", Yuxin Guo, Chenbin Rong, Zhiguo Zhang, Guilin Hu
}

Department of Energy and Environmental Systems Engineering, Zhejiang University of Science and Technology, Liuhe Road 318\#, Hangzhou, Zhejiang Province 310023, China

*E-mail: suoyg@126.com

doi: $10.20964 / 2017.05 .21$

Received: 11 January 2017 / Accepted: 2 March 2017 / Published: 12 April 2017

This work reports the synthesis of a series of carbon supported Pt-Pd-Cu (Pt-Pd-Cu/C) nano-catalysts for formic acid oxidation. The trimetallic catalysts were prepared by a one-pot protocol through reduction of $\mathrm{Pt}, \mathrm{Pd}$ and $\mathrm{Cu}$ ions using ethylene glycol and sodium citrate as the reducing and stabilizing reagents. XRD characterization suggests that $\mathrm{Pt}-\mathrm{Pd}-\mathrm{Cu}$ alloys with different lattice parameters can be successfully prepared through adjusting the atomic ratios of $\mathrm{Pt}, \mathrm{Pd}$ and $\mathrm{Cu}$ ions in the precursor solutions. The average crystal sizes of the Pt-Pd-Cu/C catalysts are in the range of 2.7$3.1 \mathrm{~nm}$. TEM images shows that the metallic nanoparticles are well dispersed on the carbon surface, with $\mathrm{Pt}_{1} \mathrm{Pd}_{3} \mathrm{Cu}_{3} / \mathrm{C}$ catalyst showing obvious aggregation. XPS was carried out to analyze the surface compositions, as well as the chemical states of the novel metals in the catalysts. The real atomic ratios of the metals in the catalysts based on ICP-OES evaluation are consistent with the stoichiometric values. Electrochemical analysis suggests that the activities the $\mathrm{Pt}-\mathrm{Pd}-\mathrm{Cu} / \mathrm{C}$ catalysts towards formic acid oxidation are dependent on the composition of the catalysts, with $\mathrm{Pt}_{1} \mathrm{Pd}_{4} \mathrm{Cu}_{2} / \mathrm{C}$ exhibiting the best performance. A mass normalized peak current density of $3.02 \mathrm{~A} / \mathrm{mg}_{(\mathrm{Pt}+\mathrm{Pd})}$ was observed on $\mathrm{Pt}_{1} \mathrm{Pd}_{4} \mathrm{Cu}_{2} / \mathrm{C}$ catalyst.

Keywords: PtPdCu, nano-catalyst, formic acid oxidation, fuel cell

\section{FULL TEXT}

(C) 2017 The Authors. Published by ESG (www.electrochemsci.org). This article is an open access article distributed under the terms and conditions of the Creative Commons Attribution license (http://creativecommons.org/licenses/by/4.0/). 